\title{
PERAN KELUARGA \\ DALAM MENINGKATKAN PENDIDIKAN SPIRITUAL ANAK
}

\author{
Oleh \\ I Ketut Gunarta \\ Dosen pada Fakultas Brahma Widya IHDN Denpasar
}

\begin{abstract}
Family is the place in which the individuals are conditioned and prepared for the roles in the societies. Parents should do the preparation, preservation, direction, and be responsible for the spiritual and physical education and development of the children. They are also the motivators, advisors, as well as the friends of the children. Based on the roles the preservation of the cultural values and institutions is obtained in the societies.

In educating the children informally, parents should play the roles in creating the harmony of the family, society, and with the God, through the practise of praying. The education can be done by: a) setting the good models to the children, $b$ ) emphasizing the importance of education, and c) controlling the children's behaviors and habits.
\end{abstract}

Key words: roles, family, education, spiritual, and children.

\section{PENDAHULUAN}

Pendidikanmerupakan suatu usaha manusia untuk membina kepribadiannya agar sesuai dengan norma-norma atau aturan di dalam masyaratakat.Setiap orang tua di dalam masyarakat dapat menjadi pendidik, sebab pendidik merupakan suatu perbuatan sosial yang mendasar untuk petumbuhan atau perkembangan anak didik menjadi manusia yang mampu berpikir dewasa dan bijak.

Orang tua sebagai lingkungan pertama dan utama dimana anak berinteraksi sebagai lembaga pendidikan yang tertua, artinya disinilah dimulai suatu proses pendidikan. Orang tua berperan sebagai pendidik bagi anakanaknya.Lingkungan keluarga juga dikatakan lingkungan yang paling utama, karena sebagian besar kehidupan anak di dalam keluarga, sehingga pendidikan yang paling banyak diterima anak adalah dalam keluarga.
Menurut Mudjijono (1995:5), perkembangan karakter seorang anak dipengaruhi oleh perlakuan keluarga terhadapnya. Karakter seseorang terbentuk sejak dini, dalam hal ini peran keluarga tentu sangat berpengaruh. Keluarga merupakan kelompok sosial terkecil dalam masyarakat. Bagi setiap orang keluarga (suami, istri, dan anak-anak) mempunyai proses sosialisasinya untuk dapat memahami, menghayati budaya yang berlaku dalam masyarakatnya.

Keluarga merupakan pranata sosial yang sangat penting artinya bagi kehidupan sosial.Para warga masyarakat mengabiskan paling banyak waktunya dalm keluarga dibandingkan dengan di tempat kerja, dan keluarga adalah wadah di mana sejak dini para warga masyarakat dikondisikan dan dipersiapkan untuk kelak dapat melakukan peranan-peranannya dalam dunia orang 
dewasa. Dan melaui pelaksanaan perananperanan itu pelestarian berbagai lembaga serta nilai-nilai budaya akan tercapai dalam masyarakat. Dapat diibaratkan bahwa keluarga adalah jembatan yang menghubungkan individu yang berkembang dengan kehidupan sosial di mana ia sebagai orang sewasa kelak harus mampu melakukan peranannya (Ihromi, 2004: 284).

Pendidikan dalam keluarga sangatlah penting dan merupakan pilar pokok pembangunan karakter spiritual seorang anak.Anak perlu didukung oleh orang dewasa di sekitarnya, baik guru maupun keluarga, untuk keberhasilan pendidikan mereka.Kesadaran ini tampaknya ditangkap pemerintah dengan mengeluarkan kebijakan baru terkait peran keluarga dalam pendidikan anak. Selain upaya memperbaiki kurikulum pendidikan, Kementerian Pendidikan dan Kebudayaan menerbitkan Peraturan Menteri Pendidikan dan Kebudayaan Nomor 11 Tahun 2015 tentang Direktorat Pembinaan Pendidikan Keluarga.

Lingkungan keluarga merupakan wahana pendidikan karakter yang pertama dan utama.Oleh karena itu, orang tua perlu ditingkatkan kemampuan sehingga memiliki kemampuan untuk melakukan pembinaan dan pengembangan karakter. Pemerdayaan di lingkungan keluarga dilakukan melalui: a) penetapan regulasi yang mendorong orang tua dapat berinteraksi dengan sekolah dan lembaga pendidikan yang terkait pembangunan karakter, b) pemberian pelatihan dan pemberian pelatihan dan penyuluhan tentang pendidikan karakter, c) pemberian penghargaan kepada para tokoh-tokoh atau oaring tua yang telah menunjukkan komitmennya dalam membangun karakter di lingkungan keluarga, dan d) peningkatan komunikasi pihak sekolah dan lembaga pendidikan terkait dengan orang tua (Gunawan, 2012:206).

Dengan demikian, bahwa peran kelurga sangat besar sebagai penentu terbentuknya spiritual anak-anaknya.Keluarga bukan hanya wadah untuk tempat berkumpulnya ayah, ibu, dan anak.Lebih dari itu, keluarga merupakan wahana awal pembentukan spiritual, moral serta penempaan karakter manusia.Berhasil atau tidaknya seorang anak dalam menjalani hidup bergantung pada berhasil atau tidaknya peran keluarga dalam menanamkan ajaran moral kehidupan.

Sehingga dalam tulisan ini diangkat rumusan masalah yaitu: 1) Apa yang dimaksud dengan peran?2) Apa yang dimaksud dengan keluarga? 3) Apa yang dimaksud dengan pendidikan? 4) Apa yang dimaksud dengan spiritual? 5) bagaimanaperanan orang tua dalam meningkatkan pendidikan spritual anak?

\section{PEMBAHASAN}

\subsection{Peran}

Menurut Poerwadarminta (1987:735) kata peran berarti pemain sandiwara, tukang lawak pada permaianan, sesuatu yang jadi bagian atau yang memegang pimpinan yang terutama.Dalam hal ini peran keluarga dimaksudkan bahwa keluarga memegang seorang anak mengenai perkembangan pendidikannya.

Peran aktif keluarga perlu didukung oleh komunikasi yang baik antara pihak sekolah dan orangtua siswa. Adanya interaksi antara orangtua dan pihak sekolah menjadi kunci berlangsungnya proses pendidikan anak yang efektif, baik di sekolah maupun di rumah.

Peran orang tua juga berkisar pada kegiatan pemeliharaan, pengasuhan, pembimbingan, dan pendidikan anak baik dari segi rohani maupun jasmani.Peran yang lebih kongkrit lagi orang tua adalah sebagai pendorong yang memberi semangat, penasehat serta teman menjadi contoh anaknya selain sebagai orang yang mencintai, yang memberi kasih sayang dan tempat bertanya anaknya.

\subsection{Keluarga}

Keluarga merupakan lembaga sosial terkecil dari masyarakat yang kompleks, karena 
di mulai dari keluarga seorang anak mengalami proses sosialisasi. Dalam keluarga, seorang anak belajar bersosialisasi, memahami, menghayati, dan merasakan segala aspek kehidupan yang tercermin dalam kebudayaan dan spritual.Hal tersebut dapat dijadikan sebagai kerangka acuan di setiap tindakannya dalam menjalani kehidupan.

Pendidikan keluarga merupakan pendidikan yang pasti dialami seseorang sejak ia dilahirkan, dan biasanya dilaksanakan sendiri oleh orang tua dan anggota keluarga yang lain (Joesoef, 1979:46).

Orang tua sebagai salah satu pihak yang bertanggung jawab dalam pendidikan sangat besar pengaruhnya terhadap perkembangan pendidikan anak.Azizy (2003:16) mengatakan bahwa:"'Orang tua harus dapat menciptakan situasi dan kondisi baik fisik maupun psikis, baik secara sosial maupun non sosial yang memadai agar tercapai prestasi belajar yang optimal. Hal ini karena keluarga mempunyai pengaruh terhadap keberhasilan murid khususnya jika orang tua bersifat merangsang, mendorong dan membimbing terhadap aktifitas belajar anaknya, sehingga memungkinkan diri anak untuk mencapai prestasi belajar yang tinggi”.

Bagi seorang anak, keluarga merupakan tempat pertama dan utama bagi pertumbuhan dan perkembangannya.Keluarga berfungsi sebagai sarana mendidik, mengasuh, dan mensosialisasikan anak, mengembangkan kemampuan seluruh anggotanya agar dapat menjalankan fungsinya di masyarakat dengan baik, serta memberikan kepuasan dan lingkungan yang sehat guna tercapainya keluarga sejahtera (Asep, 2010:91).

Dalam keluarga anak-anak pertama kalinya memperoleh pendidikan, sejak ia dilahirkan sehingga pendidikan keluarga merupakan pembentukan dasar kepribadian anak. Sebagaimana yang dinyatakan oleh $\mathrm{Ki}$ Hadjar Dewantoro (dalam Joesoef, 1979:47): "Alam keluarga adalah pusat pendidikan yang terpenting, oleh karena sejak timbulnya adat kemanusiaan hingga kini, hidup keluarga itu selalu mempengaruhi bertumbuhnya budi pekerti tiap-tiap manusia".

Menurut Subagiasta (2006:136) menyatakan bahwa sumber belajar orangtua sangat berpengaruh terhadap anak seperti berikut ini:

a. Menularkan pengalaman beajar yang berkenaan dengan hakikat serta pemahaman yang benar mengenai konsep Ketuhanan

b. Memberikan panutan tentang penglaman belajar yang menyangkut aspek-aspek kehidupan sesuai dengan ajaran Agama Hindu

c. Memberikan pengalaman belajar tentang lingkungan, budaya, mata pencaharian, teknologi, sistem pengetahuan, bahasa, lembaga-lembaga sosial, kesenian dan estetika yang berkaitan dengan kehidupan beragama.

d. Pengalaman hidup kemandirian, bertanggungjawab, polahidup hemat, pola hidup percaya diri, pemberani, harmonis.

e. Tanamkan pengalan orangtua tentang ajaran moralitas kepada anak secara kontinyu dan penuh perhatian dalam keluarga.

Sehingga keluarga merupakan tempat pertama kalinya seorang anak mendapatkan pendidikan.Orang tua merupakan pendidik dalam sebuah keluarga dan anak sebagai si terdidik.Dalam keluarga anak memperoleh pengalaman pertama yang merupakan faktor penting dalam perkembangan pribadi anak selanjutnya.Karena pengalaman pada masa anak-anak dapat mempengaruhi perkembangan seorang anak pada kehidupannya.

\subsection{Pendidikan}

Pendidikan merupakan suatu usaha manusia untuk membina kepribadiannya agar sesuai dengan norma-norma atau aturan di dalam masyaratakat.Setiap orang dewasa di 
dalam masyarakat dapat menjadi pendidik, sebab pendidik merupkan suatu perbuatan sosial yang mendasar untuk petumbuhan atau perkembangan anak didik menjadi manusia yang mampu berpikir dewasa dan bijak (Pidarta, 1997:2).

Pendidikan adalah tanggung jawab bersama antara keluarga, masyarakat, dan pemerintah.Sehingga orang tua tidak boleh menganggap bahwa pendidikan anak hanyalah tanggung jawab sekolah. Pendampingan orang tua dalam pendidikan anak diwujudkan dalam suatu cara-cara orang tua mendidik anak.Cara orang tua mendidik anak inilah yang disebut sebagai pola asuh.

Setiap orang tua berusaha menggunakan cara yang paling baik menurut mereka dalam mendidik anak. Untuk mencari pola yang terbaik maka hendaklah orang tua mempersiapkan diri dengan beragam pengetahuan untuk menemukan pola asuh yang tepat dalam mendidik anak.

Orang tua sebagai lingkungan pertama dan utama dimana anak berinteraksi sebagai lembaga pendidikan yang tertua, artinya disinilah dimulai suatu proses pendidikan. Sehingga orang tua berperan sebagai pendidik bagi anakanaknya.Lingkungan keluarga juga dikatakan lingkungan yang paling utama, karena sebagian besar kehidupan anak di dalam keluarga, sehingga pendidikan yang paling banyak diterima anak adalah dalam keluarga.

\subsection{Spiritual}

UU Nomor 2 tahun 1989 tentang Sistem Pendidikan Nasional Pasal 10 ayat (4) dinyatakan bahwa: pendidikan keluarga merupakan bagian dari jalur pendidikan luar sekolah yang diselenggarakan dalam keluarga dan yang memberikan keyakinan agama, nilai budaya, nilai moral, dan keterampilan. Tingkat pencapaian spiritual ditentukan oleh sejumlah faktorterhadap tingkat spiritual seseorang dan pertumbuhan spiritual.
Spirit mengandung arti semangat, kehidupan, pengaruh, antusiasme (Poerwadarminta, 1987:963).Spirit sering diartikan sebagai ruh atau jiwa.Jadi arti kiasannya adalah semangat atau sikap yang mendasari tindakan manusia.Di masyarakat sering terlupakan bahwa arti sebenarnya spirit itu adalah entitas atau makhluk atau sesuatu bentuk energi yang hidup dan nyata, meskipun tidak kelihatan di mata biasa dan tidak punya badan fisik seperti manusia, tetapi spirit itu ada dan hidup. Spirit bisa diajak berkomunikasi sama seperti kita bicara dengan manusia yang lain. Interaksi dengan spirit yang hidup itulah sesungguhnya yang disebut spiritual.

Spiritualitas adalah hubungannya dengan Yang Maha Kuasa dan Maha pencipta, tergantung dengan kepercayaan yang dianut oleh individu. Beberapa pakar telah mendalami secara sistematis, antara lain dalam spiritualitas meliputi aspek-aspek: 1) Berhubungan dengan sesuatau yang tidak diketahui atau ketidakpastian dalam kehidupan, 2) Menemukan arti dan tujuan hidup, 3) Menyadari kemampuan untuk menggunakan sumber dan kekuatan dalam diri sendiri, dan 4) Mempunyai perasaan keterikatan dengan diri sendiri dan dengan yang maha tinggi.

Pendidikan agama dan spiritual ini berarti membangkitkan kekuatan dan kesediaan spiritual yang bersifat naluri Ketuhanan yang ada pada anggota keluarga melalui bimbingan agama yang sehat untukmengamalkan ajaranajaran agama berupa filsafat (Tattwa), etika/ moralitas (Susila), dan mewujudkan pelaksanaan ritual atau upacara agama (Acaral Upakara). Hal ini sesuai dengan sloka yang terdapat dalam Kitab Sarasamuscaya 35sebagai berikut:

Ekam yadi bhawecchastram creyo nissamoeayam bhawet,

Bahutwadiha oeastranam guham creyah praweoitam. 
Yan tunggala kta Sang Hyang Âgama, tan sangoaya ngwang irikang sinanggah hayu, swargâpawargaphala,

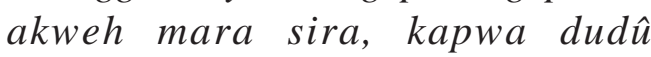
pakcanira sowing-sowang hetuning wulangin, tan anggah ring angghakna, hana ring guhâgahwara, sira sang hyang hayu.

Terjemahan:

Sesungguhnya hanya satu saja tujuan agama, seharusnya tidak sangsi lagi orang tentang yang disebut kebenaran, yang dapat membawa ke sorga atau moksa.Semua menuju kepadanya.Akan tetapi masing-masing orang berbeda caranya. Hal itu disebabkan oleh kebingungan, sehingga yang tidak benah dibenarkan, ada yang menyangka, bahwa di dalam goa yang besarlah tempatnya kebenaran (Kajeng, 2010:31)

Berdasarkan uraian teks Sarasamuscaya tersebut, menerangkan bahwa faktor pendidikan agama yang turut membentuk keluarga Hindu menurut ajaran tersebut berupa menyiapkan sarana persembahyangan untuk memahami pengetahuan-pengetahuan agama melalui sikap tauladan yang baik tentang kekuatan iman tentang Panca Sradha, Susila dan menggalakkan keterlibatan segenap anggota keluarga dalam aktivitas-aktivitas agama. Hal ini akan memberikan panutan kepada anak untuk membangkitkan spiritualnya masing-masing.

Bagi manusia,mempunyai kepercayaan atau keyakinan berarti mempercayai atau mempunyai komitmen terhadap sesuatu atau seseorang.Konsep kepercayaan mempunyai dua pengertian. Pertama kepercayaan didefinisikan sebagai kultur atau budaya dan lembaga keagamaan. Kedua, kepercayaan didefinisikan sebagai sesuatu yang berhubungan dengan Ketuhanan, Kekuatan tertinggi, orang yang mempunyai wewenang atau kuasa, sesuatu perasaan yang memberikan alasan tentang keyakinan (belief) dan keyakinan sepenuhnya (action), harapan (hope), harapan merupakan suatu konsep multidimensi, suatu kelanjutan yang sifatnya berupa kebaikan, dan perkembangan, dan bisa mengurangi sesuatu yang kurang menyenangkan. Harapan juga merupakan energi yang bisa memberikan motivasi kepada individu untuk mencapai suatu prestasi dan berorientasi kedepan.Agama adalah sebagai sistem organisasi kepercayaan dan peribadatan dimana seseorang bisa mengungkapkan dengan jelas secara lahiriah mengenai spiritualitasnya.Agama adalah suatu sistem kepercayaan yang terorganisir dan teratur.

Ungkapan istilah spiritual sering digunakan dalam percakapan sehari-hari.Untuk memahami pengertian spiritual dapat dilihat dari berbagai sumber. Menurut Oxford English Dictionary, untuk memahami makna kata spiritual dapat diketahui dari arti kata-kata berikut ini: persembahan, dimensi supranatural, berbeda dengan dimensi fisik, perasaan atu pernyataan jiwa, kekudusan, sesuatu yang suci, pemikiran yang intelektual dan berkualitas, adanya perkembanga pemikiran danperasaan, adanya perasaan humor, ada perubahan hidup, dan berhubngan dengan organisasi keagamaan. Sedangkan berdasarkan etimologinya, spiritual berarti sesuatu yang mendasar, penting, dan mampu menggerakkan serta memimpin cara berpikir dan bertingkah laku seseorang.

Secara kongkrit berdasarkan konsep tersebut, makna spiritual dapat dihubungkan dengan kata-kata makna, harapan, kerukunan, dan system kepercayaan.Dyson (dalam Azizy, 2003: 23) mengamati bahwa seseorang menemukan aspek spiritual tersebut dalam hubungan dengan seseorang dengan dirinya sendiri, orang lain dan dengan Tuhan.

Menurut Reed (dalam Endraswara, 2012:162) spiritual mencakup hubungan intra, inter, dan transpersonal. Spiritual juga diartikan sebagai inti dari manusia yang memasuki dan mempengaruhi kehidupannya dan dimani- 
festasikan dalam pemikiran dan perilaku serta dalam hubungannya dengan diri sendiri, orang lain, alam, dan Tuhan. Para ahli menyimpulkan bahwa spiritual merupakan sebuah konsep yang dapat diterapkan pada seluruh manusia.Spiritual juga merupakan aspek yang menyatu dan universal bagi semua manusia.Setiap orang memiliki dimensi spiritual.Dimensi ini mengintegrasi, memotivasi, menggerakkan, dan mempengaruhi seluruh aspek hidup manusia.

Dengan mencapai tingkatan spiritual yang tinggi, mungkin saja akan dengan sendirinya memiliki satu atau dua kemampuan paranormal. Beberapa orang yang tingkatan spiritualnya tinggi menolong menyembuhkan orang sakit.Tetapi sebaliknya,memiliki kemampuan paranormal tinggi tidak selalu spiritualnya tinggi.

Menurut Joesoef (1979:48) menyatakan bahwa pendidikan keluarga dapat pula merupakan lembaga pendidikan penting untuk meletakkan dasar pendidikan agama bagi anak. Seperti tampak pada anak-anak yang belajar tata cara sembahyang pada orang tuanya.

Sehingga dalam meningkatkan pendidikan spiritual seorang anak dalam keluarga sanggat dipentingkan dukungan dari orangtua dalam mengajarkan tata cara untuk melakukan hubungan yang harmonis dalam keluarga, lingkungan dan Tuhan melalui persembahyangan. Ajaran Agama Hindu pendidikan ini diajarkan terdapat pada Tri Hita Karana.

\subsection{Peranan Orang Tua dalam Meningkatkan Pendidikan Spritual Anak}

Sebuah keluarga yang menjadi orang tua adalah Bapak dan Ibu, di mana Bapak merupakan kepala keluarga dan Ibu sebagai pendamping dan pengatur urusan rumah tangga.Orang tua memiliki peranan yang sangat signifikan dalam urusan pendidikan non formal yang terjadi dilingkungan keluarga. Peranan orang tua dalam meningkatakan pendidikan anak-anaknya dapat dilakukan sebagai berikut: a) memberikan contoh prilaku yang baik pada anak, b) menekankan pentingnya ilmu pengetahuan pada anak, dan c) mengawasi prilaku serta kebiasaan anak. a) Memberikan contoh prilaku yang baik pada anak

Memberikan contoh untuk membentuk karakter spiritual anak sangat diutamakan agar orang tua memberikan contoh kepada anakanaknya, hal ini senada dengan Kitab Nitisastra, II 10-11 sebagai berikut:

Putras ca vividhaih silair

Nyojyah satatanam budhaih

Niti-jhah sila sampanna

Bhavanti kula pujitah

Terjemahan:

Orang bijaksana hendaknya menghajarkan putranya tata susila, pengetahuan Nitisastra dan ilmu pengetahuan suci lainnya, sebab seorang putra yang mahir dalam pengetahuan Nitisastra dan pengetahuan suci lainnya akan menyebabkan keluarga terpuji (Darmayasa, 1997:12).

\section{Mata satru pita baii \\ Yena balo na pathitah \\ Na sobhate sabha-madhye \\ Hamsa-madhye bako yatha}

Terjemahan:

Seorang bapak dan ibu yang tidak perah memberikan pelajaran (kesucian) kepada anaknya mereka berdua adalah musuh dari anak tersebut.Anak tersebut tidak aka nada terjemahan di masyarakat, bagaikan seekor bangau ditengah-tengah kumpulan burung angsa (Darmayasa, 1997:13).

Berdasarkan dua sloka diatas dapat diketahui bahwa pengetahuan tentang etika dan pengetahuansuci lainnya sangat penting untuk diberian kepada seorang anak. Seorang anak akan menjadi baik jika keluarga berperan dalam mendidiknya dengan cara baik dan tepat. Salah mendidik akan berakibat kurang baik bagi anak. Orang tua hendaknya menciptakan suasana yang kondusif demi pendidikan anak, dengan suasana yang bahagia dan gembira.

Perbuatan anak secara tidak langsung berawal dari perilaku orang tua dalam kehidupan sehari-hari.Sebagian besar perilaku yang ditunjukkan anak dalam lingkungan yang lebih luas mencerminkan demikian pula perilaku 
orang tuanya dalam keseharian.Kebanyakan para orang tua yang berperilaku acuh terhadap norma-norma yang berlaku dalam kesehariannya, kebiasaan tersebut anak menurun kepada anaknya.Disini peranan orang tua menentukan dalam pendidikan spiritual di dalam keluarga. Orang tua dalam keluarga hendaknya menjadi teladan dan menjalin komunikasi yang akrab dan hangat dengan anak-anaknya, sehingga setiap persoalan akan dipecahkan bersama.

b) Menekankan pentingnya ilmu pengetahuan pada anak

Perkembangan ilmu pengetahuan dan teknologi memegang peranan penting serta sangat mempengaruhi perkembangan sikap dan intelektualitas generasi muda sebagai penerus bangsa.Keluarga, kembali mengambil peranan penting dalam peningkatan kualitas sumber daya manusia.

Berbagai aspek pembangunan suatu bangsa, tidak dapat lepas dari berbagai aspek yang saling mendukung, salah satunya sumber daya manusia.Terlihat pada garis-garis besar haluan Negara bahwa penduduk merupakan sumber daya manusia yang potensial dan produktif bagi pembangunan nasional. Hal ini pun tidak dapat terlepas dari peran serta keluarga sebagai pembentuk karakter dan moral individu sehingga menjadi sumber daya manusia yang berkualitas.

Keberhasilan pembangunan suatu bangsa sangat memerlukan adanya sumber daya manusia yang berkualitas baik. Untuk mendapatkan sumber daya manusia yang berkualitas baik tentunya memerlukan berbagai macam cara. Salah satu diantanya adalah melalui pendidikan.Pendidikan baik formal maupun informal.Pendidikan moral melalui penetahuan agama dalam keluarga salah satunya.

Pengetahuan agama bersifat mutlak dan wajib diyakini oleh para pemeluknya. Pengetahuan berhubungan dengan agama mengandung beberapa hal yang pokok, dalam Hindu menyangkut keyakinan terhadap limahal yang disebut Panca Sraddha (Donder, 2010:16).
Dalam keluarga anak sangat penting diberikan ajaran terhadap kepercayan yang dimilikinya. Memiliki tingkat pendidikan yang tinggi, tetapi rendah dalam hal spiritual, individu tidak akan berarti dimata siapa pun. Pendidikan moral dimulai dari sebuah keluarga yamng menanamkan budi pekerti luhur dala setiap interaksinya.Sumber daya manusia berkualitas dapat dilihat dari keluarganya.Bukan hanya keluarga mampu dari segi materi, yang dapat meningkatkan kualitas individunya melalui tambahan-tambahan materi pembelajaran di luar bangku sekolah.Akan tetapi, keluarga sederhana di desa pun dapat menjamin kualitas sumber daya manusianya.Kualitas sumber daya dan keluhuran budi pekerti merupakan hasil didikan dari orang tua masing-masing.

c) Mengawasi prilaku serta kebiasaan anak

Orang tua menjadi pemegang peranan utama dalam proses pembelajaran anakanaknya, terutama di saat mereka belum dewasa. Kegiatannya antara lain melalui asuhan, bimbingan, pendampingan, dan teladan nyata. Dalam bidang pergaulan hendaknya anak tetap dikontrol. Di sisi lain, orang juga berperan mengontol keadaan bik situasi dan kondisi anak melalui teman si anak dan menghubungi guru. Di samping itu, setelah anak pulang sekolah. Orang tua dapat memeriksa tas sekolah anak, seandainya anak membawa sesuatu yang tidak wajar (Beranda, 2014:84).

Pendidikan harus dilakukan melalui tiga lingkunga yaitu lingkungan keluarga, sekolah dan organisasi.Keluarga merupakan pusat pendidikan yang pertama dan terpenting.Sejak timbulnya peradaban manusia sampai sekarang, keluarga selalu bepengaruh besar terhadap perkembangan anak manusia.Pendidikan adalah tanggungjawab bersama antara keluarga, masyarakat, dan pemerintah.Sekolah sebagai pembantu kelanjutan pendidikan dalam keluarga sebagai pendidikan yang pertama dan utama diperoleh ialah dalam keluarga (Hasan, 2009:18-19).

Sebagai orang tua dituntut untuk mengenalkan, membimbing, memberi teladan 
dan melibatkan anak dan anggota keluarga lainnya untuk mengenal kaidah-kaidah agama dan perilaku keagamaan.Di sinilah orang tua diwajibkan menjadi tokoh panutan dalam keluarga, untuk menciptakan suasana keagamaan dalam kehidupan keluarga.Pola asuh anak di bidang agama sebagai solusi terakhir dan tertinggi bagi setiap persoalan hidup anak-anak.

\section{SIMPULAN}

Besarnya pengaruh peranan keluarga dan masyarakat dalam pendidikan untuk memajukan pendidikan terlebih lagi apabila terjalinnya komunikasi yang baik antara keluarga, sekolah, dan masyarakat untuk membentuk anak didik yang berpendidikan baik dari sikap, perilaku, dan agamanya. Melalui hubungan ini menjadikannya sebagai sumber pelajaran yang baik bagi perkembangan pendidikan yang terus berkembang.Dukungan dari orangtua dalam mengajarkan tata cara untuk melakukan hubungan yang harmonis dalam keluarga, lingkungan dan Tuhan melalui persembahyangan. Peranan orang tua dalam meningkatakan pendidikan anak-anaknya dapat dilakukan beberapa hal oleh orang tuanya yaitu dengan melakukan: a) memberikan contoh prilaku yang baik pada anak, b) menekankan pentingnya ilmu pengetahuan pada anak, dan c) mengawasi prilaku serta kebiasaan anak.

\section{DAFTAR PUSTAKA}

Azizy, A. Qodri A. 2003. Pendidikan (Agama) Untuk Membangun Etika Sosial. Semarang: Aneka Ilmu.

Donder, I Ketut.I Ketut Wisarja. 2010. Filsafat Ilmu. Surabaya: Paramita.
Endraswara, Suwardi. 2012. Metodologi Penelitian Budaya. Yogyakarta: Gajah Mada University Perss.

Joesoef, Soelaiman. Slamet Santoso. 1979. Pendidikan Luar Sekolah. Surabaya: C.V. Usaha Nasional.

Mudjijono, Hermawan. dkk. 1996. Fungsi Keluarga Dalam Meningkatkan Sumber Daya Manusia. Yogyakarta: Departemen Pendidikan dan Kebudayaan.

Pidarta, Made. 1997. Landasan Kependidikan. Jakarta: PT. Rineka Cipta.

Poerwadarminta, W.J.S. 1987. Kamus Umum Bahasa Indonesia.Jakarta: Balai Pustaka.

Subagiasta, I Ketut. 2006. Siksa dan Jnana. Surabaya: Paramita.

Undang-undang tentang Sistem Pendidikan Nasional. 1989. Jakarta:Depdiknas.

Gunawan, Heri. 2012. Pendidikan Karakter Konsep dan Implementasi.Bandung: Alfabeta.

Ihromi, T.O. 2004. Bunga Rampai Sosiologi Keluarga. Jakarta: Yayasan Obor Indonesia.

Asep, Jihad, dkk. 2010. Pendidikan Karakter Teori dan Aplikasi.Direktorat Jendral Manajemen Pendidikan dan Menengah Kementrian Pendidikan Nasional.

Darmayasa, I Made. 1997. Canakya Nitisastra. Surabaya: Paramita

Hasan, Said Hamid. 2009. Pengembangan Pendidikan Budaya dan Karakter Bangsa.Kementrian Pendidikan Nasional: Badan Pengembangan Pusat Kurikulum. 